\title{
Analytical Procedures and Their Impact on Reducing Audit Risks in the Auditor's Report
}

\author{
Sawsan Fadel jassim ${ }^{1}$, Alaa Fareed Abdulahad ${ }^{2}$ \\ \{ sawsan.alansary@fgs.stu.edu.iq ${ }^{1}$, alaabotto@stu.edu.iq $\left.{ }^{2}\right\}$
}

\begin{abstract}
Faculty of Graduate Studies, Southern Technical University, Basra, Iraq ${ }^{1}$, Management Technical College, Southern Technical University, Basra, Iraq ${ }^{2}$

Abstract : The research aims to identify the concept of analytical procedures in the audit process, and the impact of their various uses in reducing audit risks in the auditor's report. The research sample was represented by a groupof auditors 'reports for a number of mixed and private joint stock companies listed in the Iraqi Securities Commission . In its practical and applied side, the study found that the diversity in the use of analytical procedures contributes to reducing the audit risk in the auditor's report, by increasing the confidence of the beneficiaries of the financial statements that they are free from the risks of discovering fundamental misstatements that affect the fairness of presenting that data. Where the use of different analytical procedures reduces the various risks to whichthe financial statements are exposed and enhances the honesty and fairness of their presentation.
\end{abstract}

Keywords : audit, analytical procedures, risk, Basra

\section{Introduction}

Analytical procedures as an audit method have recently attracted the interest of practitioners, academics, and standard setting committees. This is partly due to auditors' search for appropriate ways to reduce audit costs without sacrificing the high quality of audit services [1] . Also, the application of analytical procedures is one of the methods available to the auditor to obtain a deeper view of the entity, and can lead to more efficient and effective audits [2]. In addition, analytical procedures have the ability to provide critical information in order to evaluate past and present performance, as well as to identify warnings about the entity under audit in order to take appropriate action [3] . Moreover, one of the factors that oblige auditorsto use analytical procedures in auditing are the constraints imposed by the time frame of audit work and the great development of computing tools available to auditors [4] . Analytical procedures play an important role in a risk-based audit approach. It directs attention to areas of high risk and helps identify audit issues that the detailed audit procedures have not been able to detect. It also helps in evaluating the final audit results and providing objective evidence. Analytical procedures can also be a relatively inexpensive way to increase the auditor's confidence in the validity of the balances that are disclosed. Analytical procedures 
can range from surveying and comparing information by an experienced auditor to applying different statistical models, Analytical procedures are also of critical importance in assessing the level of risk so that the auditor can use this risk assessment to design procedures for gathering appropriate audit evidence and reducing risks when expressing his neutral technical opinion on the financial statements [5].

\section{Research Methodology}

2.1 Research Problem: Analytical procedures are one of the means to obtain proof of evidence in the auditing process that the auditor practices in performing the audit task of the entity, especially in themost important pillar of auditing, which is examination and evaluation. These procedures help in analyzing the entity's activity and the extent of potential risks, as well as identifying areas of potential errors in the financial statements, and enabling the auditor to express his neutral technical opinion on the extent of the sincerity and fairness of the financial statements. Accordingly, the research problem can be summarized by the following question: To what extent does diversity in the use of analytical procedures contribute to reducing audit risks in the auditor's report?

2.2 Research Importance: The importance of this study stems from the fact that it sheds light on the topic of analytical procedures, which is one of the most important tools and methods for gathering evidence. This is because it is applied in all stages of the audit (planning, examination, expressing an opinion), as well as drawing the auditor's attention to unusual matters in the financial statements, and its role in reducing risks.

2.3 Research Aims: The main objectives of the research can be identified as follows: (1) Understand the concept of analytical procedures in the audit process. (2)The effect of using various analytical procedures to reduce audit risks.

2.4 Research Hypothesis: In light of the problem and objectives of the research, the following main hypothesis can be formulated: The diversity in the use of methods of analytical procedures leads to reducing the risk of auditing the auditor's report.

2.5 The Research Sample: The research sample was represented by a number of auditors' reports for the Office of Financial Supervision and private auditing offices issued by the Securities Commission inIraq for mixed and private shareholding companies for the fiscal years 2018-2019.

\section{Previous Studies:}

A study (Samaha \& Hegazy2010)[1] entitled:" An Empirical Investigation Of The Use Of ISA 520 "Analytical Procedures" Among Big 4 Versus Non-Big 4 Audit Firms In Egypt" This study aimed to study International Auditing Standard No. 520 related to analytical procedures and to adapt it to analytical procedures in the context of the Egyptian audit environment. It also aimed to examine the extent to which analytical procedures are used in Egypt during the 
three audit stages, according to the size of the entitys and the number of their employees. The results of the study showed that there is a relative decrease in the use of analytical procedures by account auditors in Egypt. The study also foundthat despite the auditors' conviction in Egypt of the usefulness of using analytical procedures during theaudit process, they doubted the feasibility of using them during the detailed testing phase. The auditors in Egypt also indicated that the international auditing standard 520 did not affect the audit profession in Egypt so much. The study recommended educating the auditors in Egypt by using analytical procedures in the audit process. Pinho (2014)[4] study entitled: (The Usefulness of Analytical Procedures - An Empirical Approach in the Auditing Sector in Portugal) The study aimed to identify the practices adopted in Portugal by the entities responsible for conducting financial audits (auditing firms or individual auditors), in terms of the use of analytical audit procedures during the various auditing stages. A survey was prepared and sent by e-mail to the auditors regarding the implementation aspect. This study found that account auditors in Portugal use analytical procedures frequently in the planning .A study (Al-Abdoun et al. 2018)[6] entitled "Analytical procedures in auditing and their implications for the continuity of establishments according to the perspective of the quality of financial reports - a field study on external audit offices operating in Iraq."stage, and not in the other two auditing stages. The study aimed to identify in a comprehensive way the role played by the analytical procedures by the auditing offices operating in Iraq in achieving the quality of financial data and its reflection in the possibility of judging the continuity of entities by the auditor. The application of analytical procedures has a positive role in achieving the quality of the financial statements, ensuring the ability to judge the continuity of entities by the auditor on the financial entities subject to audit. A study (Hryhoruk, et al, 2019) [7](Organization Of Analytical Procedures At The Audit Of Continuity Of The Enterprise Activity) The study aimed at theoretical proof and the development of methodological recommendations to improve the organization of analytical procedures in auditing the continuity of the entity. The study concluded that analytical procedures should be implemented in all stages of auditing financial statements through different methodological methods of economic analysis. Their types, contents and size depend on manyfactors. The study also concluded that the auditor should follow the required quality control policies and procedures to ensure that the audit procedures are carried out in accordance with the professional standards of auditing.

\section{The Theoretical Framework for the Analytical Procedures, Auditing Risks, and the Auditor's Report}

4.1 The Concept of Analytical Procedures : They are tests or procedures aimed at verifying the reasonableness of the carrying value of one of the items of the financial statements in light of the valueestimated by the auditor for that item [8], and it also defined as the science of detecting and analyzing patterns, identifying anomalies, and extracting other useful data in the basic data or related to the subject of auditing through analysis, modeling and visualization for the purpose of planning or conducting an audit[9] , and others defined it as a procedure consisting of analyzing important results and studying deviations and correlations, as well as diagnosing the development of entity trends[7].The researchers believe that the analytical 
procedures are the various analytical methods, indicators and ratios that contribute to converting data into audit evidence that can be used in making audit decisions represented in the auditor's opinion on the entity's financialstatements.

4.2 The Importance of Analytical Procedures : Analytical procedures are very important in the auditprocess, and their importance is highlighted by the following [10] : (1) Analytical audit procedures are one of the means that an auditor may resort to in order to identify the weaknesses and strengths of the entity subject to auditing. (2) Assisting the auditor in improving the quality of the audit process. (3) The auditor can, through analytical procedures, evaluate the performance of his assistants, uncover shortcomings in their work, search for their causes and correct them.(4) Increasing theauditor's ability to detect errors. (5) It has great importance in managing the entity, as it helps it discoverthe deficiencies within the entity, and then correct them.

4.3 Types of Analytical Procedures : There are many types of analytical procedures as follows [11] : (1) Comparing the data of the entity subject to the audit with the data of the entities practicing the same activity. (2) Comparing the data of the entity subject to auditing with the corresponding data in the previous period. There are several types of comparisons in this type of analytical procedures, which are as follows: A - Comparing the balance of the current year with its equivalent in the previous year. B - Comparing the detail of the total balance with the equivalent in theprevious year. C - Calculations of percentages and financial ratios of the relations and compare them with previous years. (3) Comparing the data of the audited entity with its expectations. (4) Comparing the data of the entity subject to the audit with the expectations of the auditor.(5) Comparing the data of the entity subject to auditing with expectations using non-financial data. The researchers believe that the use of a specific type of analytical procedures depends largely on the personal judgment of the auditor, through his experience and the extent to which they can be employed in choosing the appropriate type of analytical procedures that are commensurate with the subject to auditing.

4.4 Methods of Analytical Procedures: Three levels of analytical procedures can be used [12] : (1) Descriptive analytical procedures (non-quantitative): for example, inquiring and obtaining expectations from previous audit results, auditing external (non-quantitative) information, and auditing internal (non-quantitative) information. (2) Simple quantitative analytical procedures: It isalso several types, including analysis of financial ratios such as (liquidity, activity, profitability, financing ratios, etc.), horizontal analysis, vertical analysis, estimated trend analysis, predictive testing, and budget deviation analysis. (3) Advanced quantitative analytical procedures methods: These methods include regression analysis, time series analysis, financial planning model and cash flow model.

\section{Audit Risks:}


5.1 The Concept of Audit Risk : Audit risk is the risk that the auditor will issue an unqualified opinion when the financial statements of the entity contain material misstatements [13] , And others also defined it as the risks of an auditor expressing an inappropriate audit opinion when the financial statements are materially misstated [14] . Auditrisk has also been defined as the risk that an auditor may make mistakes in expressing his opinion about the accuracy and correctness of the information presented in the financial statements [15] .

5.2 Types of Audit Risks : (1) Inherent Risk: (IR) The inherent risk is defined as the susceptibility of aparticular account balance or a particular type of transaction to error, which would be material if it is combined with errors in other balances or other types of transactions, with the absence of internal control procedures related to it [16] . (2) Control Risks: (CR) It is the process of estimating the auditor's probability of discovering errors that exceed the acceptable limit in a certain setof data in a timely manner by the internal control system [17] . (3) Detection Risks: (DR) Detection risk is defined as the risk that the auditor's objective procedures do not discover a misstatement existing in the account balance or a class of transactions that may be major, individuallyor when combined with misstatements in other balances or classes [18] .

5.3 Assessment of Audit Risks : There are four audit risk assessment tasks, which are as follows[18]: (1) Identify risks by developing an understanding of the entity and its environment, including relevant controls relating to risks, analysis of strategic risks and categories of significant transactions. (2) Relate the identified risks to what could misstate management's assertions about the existence, evaluation and measurement of transactions or assertions about rights, obligations, presentation and disclosure. (3) Determine whether the risks are of such a magnitude that they could lead to a material misstatement of the financial statements. (4) Considering the possibility that risks may lead to material misstatement of the financial statements and their impact on classes of transactions, account balances and disclosures.

5.4 Audit Risk Model (ARM) The three components of audit risk can be expressed in a theoretical model designed to help auditors understand how the assessment of each component affects the overall audit risk faced by the engagement [19]. The audit risk model that provides a framework for assessing the relationship between overall audit risk, inherent risk, control risk, and discovery risk suggests that even when deficiencies in internal control are identified, auditors can still provide an unqualified opinion by increasing their objective testing [20] . The interdependence of the three components of the audit risk model can be expressed in the figure below, which expresses the amount of audit evidence to be collected (or not collected) by the auditor for the purpose of providing reasonable assurance [21] . 


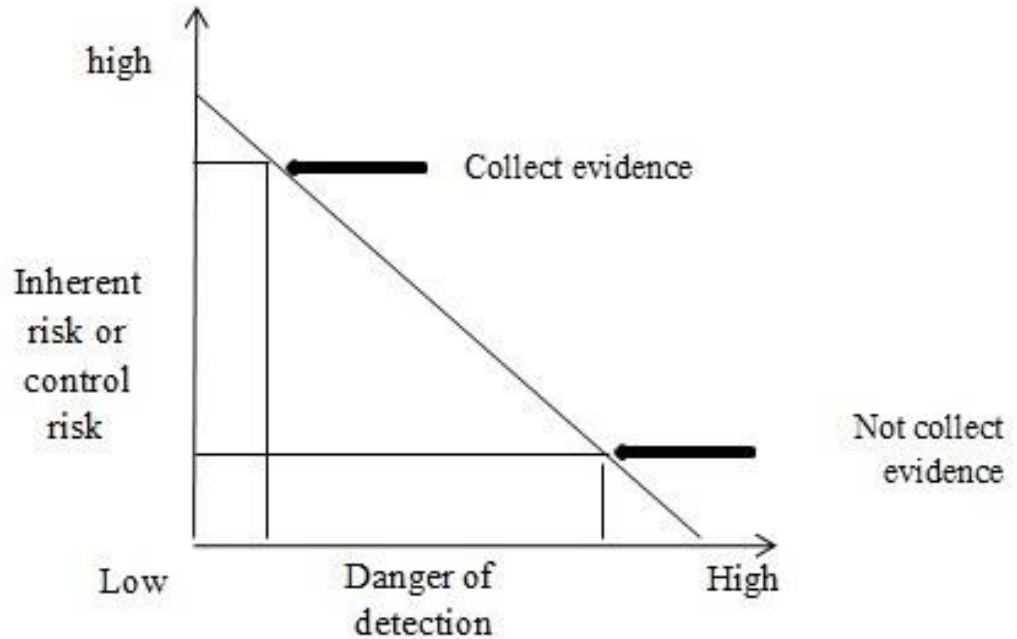

Figure (1): The relationship between inherent risks, control risks, and detection risks[21]

\section{The Auditor's Report}

6.1 The concept of the Auditor's Report : The auditor's report is a report that provides an opinion on whether the entity's financial statements and related disclosures are presented in accordance withgenerally accepted accounting principles, and this opinion is based on the control tests and objective procedures that were performed during the audit process [19] . It is also defined asthe auditor's opinion as to whether the annual financial statements give a true and fair view in accordance with the appropriate framework and, where appropriate, and whether the annual financial statements comply with the legal requirements [22].

6.2 Types of the Auditor's Report : The auditors may express four types of opinions [19] : (1) Unreserved opinion: the auditor concludes that the financial statements present the financial position, results of operations and cash flows in accordance with generally accepted accounting principles. (2) Reserved opinion: The conclusion is that, with the exception of one or moreissues, the financial statements present the financial position, results of operations and cash flows in accordance with generally accepted accounting principles. Qualified opinions use the phrase except to describe issues that lead to a reservation. (3) Negative opinion: in which the auditor concluded that thefinancial statements do not present the financial position, results of operations, and cash flows in accordance with generally accepted accounting principles. (4) Refusal to express an opinion: the auditors do not express an opinion on the fairness of the entity's financial statements .

\section{The Applied Aspect of Research}


This axis extrapolates the most important observations, reservations and clarifications found in the auditors' reports for the research sample, which was represented by a number of mixed and private joint-stock companies. It will deal with both the reports of the Federal Office of Financial Supervision concerning mixed joint-stock companies and the reports of the private audit offices, which concern the private joint-stock companies for the two fiscal years 2018-2019. This axis will be a practical identification of the types of analytical procedures that are used by the auditors in their reports and theirreflection in reducing audit risks.

7.1 Extrapolation of the auditors' reports (Ban of Financial Supervision / Mixed Joint Stock Companies) : Report of the Financial Supervision Bureau of the Iraqi Company for the Production andMarketing of Meat and Field Crops.

\subsubsection{Notes, reservations and clarifications for the fiscal year 2018}

Note (1): The management report's lack of many indicators required to disclose the reality of the company's activity and the extent of developments taking place in it, contrary to the requirements of Accounting Rule No. (6) issued by the Accounting and Regulatory Standards Board in the Republic of Iraq regarding (disclosure of information related to financial statements and accounting policies ). Analytical procedure: The analytical procedure used in this note represents a descriptive (non- quantitative) analytical procedure by referring to the accounting rules. The risks it limits: Referring to the accounting rules as an analytical procedure contributes to reducing the risks of discovering violations of the requirements of the rules that should be applied.

Note (2): The company's delay in holding the general assembly meeting for the purpose of discussing and approving the company's financial statements for the year ended on 31/12/2017 issued by the Federal Office of Financial Supervision by virtue of its book No. (B 8/29/27/10438) on 5/20/ 2018 fora period of 159 days. The meeting was held on December 29, 2018 of Article (135) of the Companies Law No. (21) of 1997 (amended), as explained in paragraph (5-a-first) of the report on page (7).

Note (3): The company was late in approving the planning budget, as it approved it on 4/16/2018, contrary to Article (117 fourth) of the amended Companies Law No. (21) of 1997. As explained in paragraph (5-a-third) of the report on page (8). Analytical procedure: The analytical procedure used in the previous notes also represents a descriptive (non-quantitative) analytical procedure, but by referringto the applicable laws represented by the Companies Law. Risks Reduced: This analytical procedure contributes to reducing the risk of discovering violations of the laws for which financial statements should be prepared in accordance with their requirements.

Note (4): The Company has not performed tax accounting for its activities for the fiscal year/2017, in violation of Income Tax Law No. (113) for the year 1982 (as amended). \} As 
explained in paragraph (5-b) of the report on page (8) Analytical procedure: The analytical procedure used represents a descriptive (non-quantitative) analytical procedure, but by referring to the applicable laws represented by the tax law. The risks it limits: This analytical procedure contributes to reducing the risks of discovering violations of the laws that must be adhered to.

Note (5): There is no proportionality between the allowance account for doubtful debts, the balance of which is (5123) thousand dinars (five million, one hundred and twenty-three thousand dinars) and revolved from previous years, and the balance of the debtors account amounting to (5072629) thousanddinars (five billion seventy-two million Six hundred and twenty-nine thousand dinars as on December 31, 2018. Analytical procedure: The analytical procedure used in the two previous notes represents a simple quantitative analytical procedure (horizontal analysis) by comparing the balances of the year subject to audit with the balances of previous years. Risks that it limits: This analytical procedure contributes to reducing the risk of discovering material misstatements in the account balances referred to in the previous two paragraphs.

\subsubsection{Notes, reservations and clarifications for the fiscal year 2019}

1. Financial statements: By matching the financial statements and analytical statements with the trial balance for the year under audit. We noticed an increase and decrease between the balances recorded in the financial statements presented to us. And the trial balance, despite the reference to it in our report for the previous year, shows the number (B/8/29/27/12584) on 30/5/2019 regarding the financial statements for the year 2018 . $30 / 6 / 2020$ and indicated that it will address these differences in the following year, as shown in the table below.

Table 1: Differences in account balances for the Iraqi company for the production and marketing of meat and field crops for the year 2019 . 


\begin{tabular}{|c|c|c|c|c|c|}
\hline $\begin{array}{c}\text { the } \\
\text { difference } \\
\text { /dinars }\end{array}$ & $\begin{array}{c}\text { Balance } \\
\text { undertrial } \\
\text { balance }\end{array}$ & $\begin{array}{c}\text { Balance under } \\
\text { dinars }\end{array}$ & $\begin{array}{c}\text { List name } \\
\text { or } \\
\text { statement }\end{array}$ & Account name & $\begin{array}{c}\text { Accounting } \\
\text { guide } \\
\text { number }\end{array}$ \\
\hline 1 & 2538992359 & 2538992358 & $\begin{array}{c}\text { fixed } \\
\text { assets }\end{array}$ & $\begin{array}{r}12 / 31 \text { building } \\
\text { cost }\end{array}$ & 112 \\
\hline 1 & 520272358 & 520272359 & $\begin{array}{c}\text { fixed } \\
\text { assets }\end{array}$ & $\begin{array}{c}\text { machinery and } \\
\text { equipment12/31 }\end{array}$ & 113 \\
\hline 1 & 132472981 & 132472983 & $\begin{array}{c}\text { Fixed } \\
\text { assets }\end{array}$ & $\begin{array}{c}\text { The cost of } \\
\text { transportation in } \\
12 / 31\end{array}$ & 114 \\
\hline 1 & 1700492582 & 1700492583 & Fixed \\
assets & $\begin{array}{c}\text { Building } \\
\text { allowance balance } \\
\text { in12/31 }\end{array}$ & 2312 \\
\hline$(1)$ & 3034028353 & 3034028352 & reserves & Reserves & 231 \\
\hline
\end{tabular}

Source: The Iraqi Securities Commission

Analytical Procedure: In this note, two types of analytical procedures were used. The first is a simple quantitative analytical procedure by comparing data and discovering differences, while the second is a non-quantitative procedure represented by inquiry from the responsible authorities in the company. The Risks That it Limits: The analytical procedures used in this note contribute to reducing the risks of discovering major misstatements in the account balances referred to in the previous table.

2. Management Report: The report of the Board of Directors submitted on the company's activity for the year ended December 31, 2019 still lacks some information and indicators, which constitutes a violation of Accounting Rule No. (6) issued by the Accounting and Regulatory Standards Board in the Republic of Iraq regarding (disclosure of information related to financial statements And the policies and below are the most important of those indicators: (1) Disclosure ofthe investment return with a statement of its development for at least three years. (2)A statement of the debts owed by others and the amounts collected during the year.(3) activities and expansions during the year and in the near future.Analytical procedure: The analytical procedure used is a descriptive (nonquantitative) procedure, which is to review the accounting rules to ensure their application.The risks it limits: This procedure limits the risks of discovering a major misstatement, which is a violation of accounting rules.

3. The Result of the Company's Activity: The result of the activity for the current operations (the first phase of the operational activity showed a surplus of) $(366,468)$ thousand dinars (three hundred and sixty-six million four hundred and sixty-eight thousand dinars), an increase of $(5,301)$ thousand dinars (five million three hundred and one thousand dinars, at a rate of $15 \%$ over the previous year of (361167) one thousand 
dinars (three hundred and sixty-one million, one hundred and seven Sixty thousand dinars) while the result of the activity in (the second phase / total activity) was a surplus of (640552) one thousand dinars (six hundred and forty million five hundred and fifty two thousand dinars) with an increase of (201515) one thousand dinars (one hundred eighty million one hundred and thirty five thousand dinars) ) at a rate of (39\%) for the previous year, which amounted to (640418) thousand dinars (sixty-four million four hundred and eighteen thousand dinars. Our study of the results of the activity showed the following indicators:

(A) An increase in the current activity revenue account by (152452) thousand dinars (one hundred and fifty-two million four hundred and fifty-two thousand dinars) and at a rate of $(15 \%)$ over the previous year of $(1017,836)$ thousand dinars (one billion and seventeen million eight hundred and thirty-six thousand dinars). The increase in the account of the revenue from the sale of waste, the revenue of various services, the rent of fixed assets (except for lands), and the increase in the interest on the lease of credit lands as a result of the company fixing its dues.Analytical procedure: The procedure used in this note is the horizontal comparison between two years for the same account.The risks it limits: This measure contributes to limiting the detection of major misstatements in the account in question.

(B) The results of implementing the planning budget: The table below shows the revenues, expenses and profit achieved from the company's activity compared to what is planned under the company's planning budget for the year subject of the report:

Table 2 : Comparing the planned and actual revenues and expenses of the Iraqi company for the production and marketing of meat and field crops for the year 2019.

\begin{tabular}{|c|l|c|c|c|}
\hline (\% 1/3per.) & $\begin{array}{c}\text { difference / } \\
\text { Thousand } \\
\text { dinars(3) }\end{array}$ & $\begin{array}{c}\text { Actual amount/ } \\
\text { Thousand } \\
\text { dinars } \\
(2)\end{array}$ & $\begin{array}{c}\text { planned amount } \\
\text { /Thousand } \\
\text { dinars } \\
(1)\end{array}$ & Statement \\
\hline$(88)$ & $(684443)$ & 1463364 & 778921 & Revenues \\
\hline$(54)$ & $(288337)$ & 822812 & 534475 & Expenses \\
\hline$(162)$ & $(396106)$ & 640552 & 244446 & Profit \\
\hline
\end{tabular}

Source: The Iraqi Securities Commission

It is evident from the above table that: Inaccuracy in preparing the planned estimates for some accounts, as shown in the table below, according to the company's response to our inquiry No. (2) on 9/3/2020:

Table 3: The company's answer to the inquiry of the Office of Financial Supervision . 


\begin{tabular}{|c|c|c|c|c|c|c|}
\hline Company's answer & $\begin{array}{c}\text { per, } \\
1 / 3 \\
(\%\end{array}$ & $\begin{array}{c}\text { Difference } \\
\text { thousand } \\
\text { dinars }\end{array}$ & $\begin{array}{c}\text { Actual } \\
\text { amount } \\
\text { thousand } \\
\text { dinars } \\
(2)\end{array}$ & $\begin{array}{c}\text { Planned no. } \\
\text { thousand } \\
\text { (1) dinars }\end{array}$ & $\begin{array}{c}\text { Name of } \\
\text { account }\end{array}$ & $\begin{array}{c}\text { No. } \\
\text { Of } \\
\text { guide }\end{array}$ \\
\hline $\begin{array}{c}\text { The reason for this is due to the } \\
\text { settlement of some amounts } \\
\text { related to the fiscal year 2014 }\end{array}$ & $(11)$ & 2292 & 19458 & 21750 & $\begin{array}{c}\text { transfer } \\
\text { expenses }\end{array}$ & 38 \\
\hline $\begin{array}{c}\text { The reason is due to the } \\
\text { calculation of profits received } \\
\text { from the Iraqi Company for } \\
\text { Seed Production at a rate of } \\
\text { (50\%), while profits were } \\
\text { received at a rate of (20\%) } \\
\text {.only }\end{array}$ & $(33)$ & $(29478)$ & 61142 & 90620 & $\begin{array}{c}\text { Benefits } \\
\text { and } \\
\text { rentals }\end{array}$ & 46 \\
\hline
\end{tabular}

Source: The Iraqi Securities Commission

Analytical procedure: The analytical procedure used in the above paragraph is to compare the data of the entity under audit with its expectations by comparing the planning budget figures with the actual figures in order to verify the correctness of the balance.The risks that it limits: This analytical procedure contributes to reducing the risks of discovering major deviations in the actual account balances from what is planned.

\subsection{Extrapolating the auditors' reports (private auditing offices / private joint stock companies)}

(A) Report of the auditor of the Iraqi Company for Carpets and Furniture

\section{Notes, reservations and clarifications for the fiscal year 2018}

Note (1): The management report is in agreement with the Companies Law No. 21 of 1997 as amended. Analytical procedure: The analytical procedure used in the analysis of this illustration represents a descriptive (non-quantitative) analytical procedure through reference to the applicable laws. The risks that it limits: This analytical procedure contributes to reducing the risks of discovering violations that include misrepresentation in the financial statements as a result of non-compliance with laws.

Note (2): The stock of the finished production was evaluated at the end of the period at the cost of manufacture. As for the incomplete production, it was evaluated according to the stages of production, according to the principles adopted in this field and based on the accounting rule No. (5) issued by the Accounting Standards and Rules Board in the Republic of Iraq.

Analytical procedure: This clarification refers to the auditor's reference to the accounting rules as a descriptive (non-quantitative) analytical procedure. The risks it limits: This procedure contributes to reducing the risks of discovering major violations resulting from non- 
compliance with accounting rules.

Note (3) : The results of executing the company's production plan showed that no actual results were achieved for the planned quantities of carpet products, floor furnishings, and filters, noting that the planning was done for the entire available capacity and the following table shows:

Table 4: The planned and actual production capacity of the Iraqi Company for Carpets and Furniture for the years 2017-2018

\begin{tabular}{|c|c|c|c|c|c|}
\hline \multicolumn{2}{|c|}{20} & \multicolumn{2}{c|}{2018} & measuring unit & Product Type \\
\cline { 1 - 2 } 17 & Planed & outlet & Planned & & \\
\hline------ & 2000 & ------ & 2000 & $\mathrm{M}^{2}$ & Carpet \\
\hline------ & 3000 & ------ & 3000 & $\mathrm{M}^{2}$ & $\begin{array}{c}\text { Furniture and } \\
\text { flooring }\end{array}$ \\
\hline 2200 & 5000 & 2200 & 5000 & $\mathrm{M}^{2}$ & Filters \\
\hline
\end{tabular}

Source: The auditor's report published in the Iraqi Securities Commission

Analytical Procedure: In the above note, a comparison between the planned figures is used in theentity's estimated and actual budget. Another procedure is used, which is horizontal analysis by comparing two different years for the same accounts. Risks that it limits: The aforementioned procedure contributes to reducing the risk of differences between what is planned and the actualnumbers, and thus discovering deviations, if any.

\section{Notes, reservations and clarifications for the fiscal year 2019.}

Note(1): The management report is in agreement with the Companies amended Law No. 21 of 1997. Analytical Procedure: The previous analytical procedure represents a descriptive (non-quantitative) analytical procedure by referring to the applicable laws and comparing them with the data of the entity subject to auditing. Risks that it limits: This procedure contributes to reducing the risk of discovering violations that include material misstatement of the financial statements as a result of non-compliance with laws.

Note(2): The stock of finished production was evaluated at the end of the period at the cost of manufacture. As for the incomplete production, it was evaluated according to the stages of production according to the principles adopted in this field and based on the accounting rule No. (5) issued by the Accounting Standards and Rules Board in the Republic of Iraq. Analytical procedure: This clarificationindicates that the auditor performed a descriptive (nonquantitative) analytical procedure, represented by indicating the extent of compliance with the accounting rules. The risks that it limits: This procedure will enhance the confidence of the users of the financial statements that the company has carried out itsbusiness in accordance with the accounting rules, and also contributes to reducing the risks of discovering material violations resulting from non-compliance with the accounting rules. 
Note(3): The results of the implementation of the company's production plan showed that no actual results were achieved for the planned quantities for each of the carpet products, floor furnishings and filters, noting that planning was done for the full available capacity and the following table shows:

Table 5 : The planned and actual production capacity of the Iraqi Company for Carpets and Furniture for the years 2018-2019

\begin{tabular}{|c|c|c|c|c|c|}
\hline \multicolumn{2}{|c|}{2018} & \multicolumn{2}{c|}{2019} & Measure unit & Product type \\
\hline outlet & planned & outlet & Planned & & Carpet \\
\hline------ & 2000 & ------ & 2000 & $\mathrm{M}^{2}$ & $\mathrm{M}^{2}$ \\
\cline { 1 - 2 } & 3000 & ------ & 3000 & $\begin{array}{c}\text { Carpet and } \\
\text { floor }\end{array}$ \\
\hline 2200 & 5000 & 3000 & 5000 & $\mathrm{M}^{2}$ & Filters \\
\hline
\end{tabular}

Source: The auditor's report published in the Iraqi Securities Commission

Analytical procedure: The comparison between the planned and the actual is the procedure used in the previous note in addition to the comparison between two consecutive years. Risks that it limits: The aforementioned procedure contributes to reducing the risk of discovering differences between what is planned and the actual numbers, and thus discovering deviations, if any.

(B) The report of the auditor for Al-Zorah Financial Investment Company / private shareholding

Notes, reservations and clarifications of the financial statements for the year 2019

Note (1) The result of the company's activity for the current year showed a deficit of $(5,777,981)$ dinars, thus the accumulated deficit amounted to (479474) 121 dinars, and after adding the amount (704445243) dinars, which represents the decrease in the allowance for depreciation in the value of investments, the total accumulated deficit becomes (825924717) Dinars, at a rate of ( $72 \%$ of the capital), which requires observing the first paragraph of Article (76) of the amended Companies Law No. 21 of 1997. Analytical Procedure: A descriptive (non-quantitative) analytical procedure was used, represented by reference to the applicable laws, which is the Companies Law. Risks limits: The use of the previous analytical procedure contributes to reducing the risk that the financial statements include violations of laws.

Note (2) The company has taken adequate measures to prevent money laundering or terrorism financing, and these measures are being implemented in accordance with the Money Laundering Law No. 39 of 2015 and the regulations and instructions issued by the Central Bank of Iraq. Analytical Procedure: A descriptive (non-quantitative) analytical procedure represented by reference to the applicable laws, which is the Money Laundering Law. Risks limits: The use of the previous analytical procedure contributes to reducing the risk that the financial statements may include violations of laws. 


\section{Conclusion}

In light of the analyzed data, the researchers conclude that the diversity in the use of analytical procedures contributes to reducing the audit risk in the auditor's report, by increasing the confidence of the beneficiaries of the financial statements that they are free from the risks of discovering fundamentalmisstatements that affect the fair presentation of that data. The use of different analytical procedures reduces the various risks to which the financial statements are exposed and enhances the truthfulness and fairness of their presentation. In addition, the researchers also conclude that there is a discrepancy between the use of analytical procedures in preparing reports by auditors in the Office of Financial Supervision, and their use by auditors in private audit offices. As methods of quantitative and non- quantitative analytical procedures are used on a larger scale in the reports prepared by the auditors in the Office of Financial Supervision, while their use in private audit offices is limited to minor observations, and there is a weakness in the use of quantitative analytical procedures, as most of the procedures used are They are descriptive (non-quantitative) procedures. Based on the previous conclusions, the researchers recommend the necessity of using analytical procedures by the account auditors when auditing the financial statements of the entities subject to auditing, and the diversity in theiruse, taking into account that they are compatible with the accounts balances that are being audited. Thisconfirms the validity of the research hypothesis.

\section{References}

[1]Samaha , K. \& Hegazy, M. (2010). "An Empirical Investigation Of The Use Of ISA 520 "Analytical Procedures” Among Big 4 Versus Non-Big 4 Audit Firms In Egypt." Managerial Auditing Journal.

[2] Kritzinger, J. A. (2016) " The application of analytical procedures in the audit process " (Doctoral dissertation, University of Pretoria).

[3] Moolman , A. M. (2017). "The usefulness of Analytical Procedures, other than ratio and trend Analysis, for Auditor decisions ". International Business \& Economics Research Journal (IBER), Vol (16), NO (3) .

[4] Pinho , C. (2014) . " The Usefulness of Analytical Procedures - An Empirical Approach in the Auditing Sector in Portugal " 24-33.

[5] Lusk , E. J., \& Halperin , M. (2016) " Client risk calibration in PCAOB audits: an analytical procedures panel risk assignment protocol." International Journal of Auditing Technology 3.1: 1-21.

[6] Al-Abdoun, H. F. \& Mansour, Abdul Rahman Al-Bakri \& Hussein, Sat Salih(2018). " analytical procedures in auditing and their implications for the continuity of enterprises according to the perspective of the quality of financial reports - a field study on external audit offices operating in Iraq" Journal of Graduate Studies / Al-Nilein University, Volume (11), Issue (42).

[7] Hryhoruk, P. M., Perevozova, I. V., Prystupa, L. A., Abesinova, O., \& Melnyk, N. (2019)." Organization of analytical procedures at the audit of continuity of the enterprise activity".

[8] Abu Samhadana, N. A.(2006) . " The fields of contribution of the use of analytical review in planning and performing the audit process - an analytical study of the opinions of auditors in audit offices and companies inthe Gaza Strip - Palestine" Master Thesis of the Islamic University - Gaza / Faculty of Commerce.

[9] Li, H., Dai, J., Gershberg, T., \& Vasarhelyi, M. A. (2018). "Understanding usage and value of audit analytics for internal auditors: An organizational approach. International Journal of Accounting Information Systems, 28, 59-76.

[10] Musa, Ali M. (2013). (Analytical review procedures and their role in rationalizing the personal judgment of the references), The Whole Journal, Issue (2), Volume (15). 
[11] Arens , Alvin A , Randal J. Elder , Mark S. Beasley , Chris. E. Hogan.(2017). " Auditing And Assurance Services - An Integrated Approach " 16 TH Edition Prentice Hall .

[12] Ayat, Asma. (2015). " the use of analytical procedures in auditing and the quality of financial reports a case study of the Sidi Arghis Mills Foundation" (Master Thesis of Umm El-Bouaghi University / College of Economic Sciences, Business Sciences and Management Sciences .

[13] Willekens , M. (2011) . " Discussion of "Short Interest as a Signal of Audit Risk " Contemporary Accounting Research, Vol (28), No (4): 1298-1303.

[14] Okeyo \& Awino, L. ( 2014 ). " Audit risk assessment and detection of misstatement in annual reports for audit firms registered by Rab in Nairobi County ", Kenya Okeyo, Inda. Diss. Egerton University.

[15] Nikolovskia , P. \& Zdravkoskib , I. \& Menkinoskic , G. \& Dičevskad , S. \& Karadjova , V.(2016). " The concept of audit risk " International Journal of Sciences: Basic and Applied Research (IJSBAR), Vol (27), No ( 1 ): 22-31.

[16] Al-Quraishi, I. R. (2011). " external audit / scientific, theoretical and applied approach", Al-Muizz House for Printing and Publishing / Depository Number in Dar Al-Kutub in Baghdad 716.

[17] Younes, Z. \& Issa, Z.(2016). (The risks of the audit profession on the quality of the audit - an analytical study of the opinions of a sample of external auditors in Algeria) Economic Visions Journal / University of the Martyr Hama Lakhdar, El-Oued, Algeria Issue (11).

[18] Hayes , R. \& Dassen , R. \& Schilder , A. \& Wallage, P . (2005). " Principles Of Auditing - An Introduction to International Standards on Auditing " $2^{\mathrm{TH}}$ Edition .

[19] Louwers, T.J. \& Blay, A. D. \& Sinason, D. H. \& Strawser, J. R. \& Thibodeau , J. C. 2018. " Auditing \& Assurance Services " $7^{\mathrm{TH}}$ Edition .

[20] Hogan, C. E., \& Wilkins , M. S. (2008). " Evidence on the audit risk model: Do auditors increase audit fees in the presence of internal control deficiencies? " Contemporary Accounting Research , Vol (25), No ( 1 ): 219-242.

[21] Zaiceanu, A. \& Hlaciuc, E. \& Lucan , A. N.C. (2015) . "Methods for risk identification and assessment in financial auditing." Procedia Economics and Finance, Vol (32): 595-602 .

[22] Muñoz - Izquierdo , N. \& Segovia-Vargas, M. J. \& Pascual-Ezama, D. (2019). " Explaining the causes of business failure using audit report disclosures" Journal of Business Research Vol (98) : 403 - 414. 